\title{
Interaksjoner mellom warfarin og naturmidler
}

\author{
Mange pasienter bruker naturmidler som kan interagere med warfarin \\ og gi blødning eller nedsatt antikoagulerende effekt. Hva vet vi om disse \\ produktene og deres interaksjonsrisiko?
}

Se også kunnskapsprøve på www.tidsskriftet.no/quiz

\author{
Vigdis Solhaug \\ vigdis.solhaug@relis.ulleval.no \\ Cecilie Sogn Nergård \\ RELIS Øst \\ Oslo universitetssykehus, Ullevål \\ 0407 Oslo
}

Før høy eller for lav INR-verdi øker risikoen for henholdsvis blødning eller tromboemboli. Økt INR-verdi og blødning er alvorlige bivirkninger av warfarin, og det rapporteres hvert år omkring 80 slike hendelser. Antall rapporterte fatale tilfeller har ligget på rundt 30-40 de siste årene (1). Årsaken til blødning kan være interaksjon med legemidler, men også naturmidler. I denne artikkelen brukes «naturmidler» som en fellesbetegnelse på produkter som inneholder planter i mer eller mindre bearbeidet form, og som enten er underlagt Statens legemiddelverks eller Mattilsynets ansvarsområde (ramme 1).

I Norge omsetter helsekostbransjen for flere milliarder kroner årlig. Studier har vist at $17-27 \%$ av pasientene på antikoagulantia også tar ulike typer naturmidler (2). I en britisk studie av warfarinpasienter oppga så mange som $44 \%$ at de brukte kosttilskudd ukentlig eller oftere (3). Det er en vanlig misforståelse at naturmidler er naturlige og derfor ufarlige. I reklamer fremstilles ofte produktene som effektive og uten bivirkninger eller interaksjoner med legemidler. Bruk av stadig mer oppkonsentrerte planteekstrakter og kombinasjonspreparater med en rekke urter øker risikoen for bivirkninger og interaksjoner med legemidler. Tall fra Storbritannia viser at $90 \%$ av pasientene ikke diskuterer bruk av naturmidler med legen $\sin (4)$. Denne artikkelen viser eksempler på interaksjoner mellom naturmidler og warfarin og belyser hvorfor det er viktig at legen har en dialog med pasientene om bruk av slike midler.

\section{Materiale og metode}

Artikkelen er basert på forfatternes egne erfaringer innen feltet, supplert med ikke-systematiske søk i PubMed og Embase samt annen relevant litteratur, inkludert søk i interaksjonsdatabasene Interaktionsdatabasen.dk og LexiInteract fra Lexi-Comp (Helsebiblioteket). Siste søk ble gjort primo juni 2009.

\section{Interaksjonsmekanismer}

Warfarin har antikoagulerende effekt ved hemming av de vitamin K-avhengige koagulasjonsfaktorene II, VII, IX og X. Legemidler, naturmidler og mat kan interagere med warfarin og gi økt risiko for blødning eller trombose. I noen tilfeller er det uklar interaksjonsmekanisme, mens kjente mekanismer omfatter endret biotilgjengelighet av warfarin som følge av endret absorpsjon eller metabolisme. Hemming eller induksjon av metabolismeenzymene CYP2C9, CYP1A2 og CYP3A4 vil gi henholdsvis økt blødningsrisiko eller nedsatt antikoagulerende effekt (fig 1). Av disse enzymene er det CYP2C9 som er viktigst, da den mest potente isomeren, S-warfarin, omdannes over dette enzymet. Effekten av warfarin kan også nedsettes av preparater og mat som innholder vitamin $\mathrm{K}$. Noen planter inneholder kumarinderivater, og enkelte av disse kan ha antikoagulerende aktivitet og øke blødningsrisikoen i kombinasjon med warfarin. Effekt og sikkerhet, inkludert interaksjoner, monitoreres ved jevnlig måling av INR-verdi. Imidlertid vil stoffer som i seg selv gir økt blødningstendens, slik som blodplatehemmere, også øke blødningsfaren i kombinasjon med warfarin uten at INRverdien påvirkes (5).

\section{Dokumentasjon}

De fleste naturmidler er ikke systematisk undersøkt med tanke på interaksjon med warfarin. Dokumentasjonsgrunnlaget for interaksjoner mellom warfarin og naturmidler er hovedsakelig kasusrapporter av varierende kvalitet. Slike kasuistikker utgjør likevel nyttig informasjon, fordi en rapportert interaksjon hos en eller flere enkeltpasienter kan indikere risiko også for andre pasienter. Det finnes eksempler på at interaksjonsstudier ikke har kunnet reprodusere funn i kasuistikker. Dette gjenspeiles også ved at ulike interaksjonsdatabaser ikke inkluderer de samme interaksjonene (tab 1) (5-7) og at risikoen blir ulikt klassifisert. For tranebær er det flere rapporter om økt INR-verdi hos warfarinbrukere, mens man i studier ikke har funnet noen interaksjon (2). Ulike innholdsstoffer i forskjellige preparater kan være en forklaring på dette. Innholdsstoffene $\mathrm{i}$ en plante vil variere avhengig av vekstvilkår, innhøstingstidspunkt og videre bearbeiding av plantematerialet. Det er derfor viktig at planteekstraktene er godt definert (standardisert) og at ekstraksjonsbetingelser og innhold av alle de antatt virksomme substanser er godt beskrevet. Dette mangler ofte for kosttilskudd og betyr at innholdsstoffene og mengden av disse kan variere mellom ulike produksjonsnummer. Pasienten kan dermed risikere endringer i for eksempel INR-verdi ved overgang til nytt produksjonsnummer selv om produktnavnet er det samme. Det er god grunn til å tro at det finnes interaksjoner med naturmidler som per i dag ikke er kjent.

\section{Klinisk relevante interaksjoner}

Tabell 1 gir en oversikt over noen aktuelle naturmidler der det er sett interaksjoner med warfarin. Det er godt kjent at johannesurt interagerer med mange legemidler, deriblant warfarin, pga. induksjon av cytokrom P-450-enzymer i lever. Dette kan resultere i nedsatt effekt av warfarin og dermed økt risiko for trombose. Flere kasuistikker har vist redusert INR-verdi hos warfarinpasienter som har inntatt johannesurt, og $\mathrm{i}$ en studie viste man at johannesurt nedsetter arealet under konsentrasjonstidskurven (AUC) for warfarin med ca. 25\% (Interaktionsdatabasen.dk). Også ginseng og soyapreparater kan gi redusert INR-verdi og økt tromboserisiko hos pasienter som bruker warfarin $(5,6)$. Grønn te kan inneholde betydelige mengder vitamin $\mathrm{K}$, som kan motvirke effekten av warfarin (6).

Dong quai er en kinesisk urt som brukes ved menstruasjonsbesvær. To kasusrappor-

\section{Hovedbudskap}

- Warfarinpasienter bør vise varsomhet ved bruk av naturmidler

- Spør alltid pasienten om bruk av naturmidler

- Helsepersonell bør melde mistenkte interaksjoner og bivirkninger av naturmidler til RELIS 


\section{Ramme 1 \\ Naturmidler (plantebaserte produkter) og regelverk \\ Naturlegemidler og tradisjonelle plantebaserte legemidler \\ - Godkjent av Statens legemiddelverk \\ - Oppfyller like strenge krav til kvalitet som vanlige legemidler \\ - For dokumentasjon av sikkerhet og effekt kreves at det aktuelle produktet eller tilsvarende produkt skal ha vært i medisinsk bruk i 30 år, hvorav minst 15 år i EØS-området \\ - Faller inn under legemiddelloven \\ Er underlagt Statens legemiddelverk \\ Kosttilskudd \\ - Ikke godkjent av Statens legemiddelverk \\ - Er for eksempel plantebaserte produk- ter, ikke-plantebaserte produkter eller vitamin- og mineraltilskudd som omsettes i ferdigpakket og dosert form beregnet til å inntas i små oppmålte mengder \\ - Faller inn under kosttilskudds- forskriften \\ - Er underlagt Mattilsynet}

ter har vist markant økning av INR-verdi ved kombinert bruk av warfarin $(5,6)$. Mekanismen er ikke klarlagt, men urten er rik på kumarinderivater, som kan ha antikoagulerende egenskaper (8). Dvergpalme, som brukes ved vannlatningsproblemer, har også gitt INR-stigning hos warfarinpasienter. En in vitro-studie har vist at dette kan skyldes at dvergpalme har en sterk hemmende effekt på CYP2C9 og CYP3A4 (7).

Hvitløk kan hemme blodplateaggregeringen og dermed gi forlenget blødningstid. Det er uklart hvor mye hvitløk som må inn-

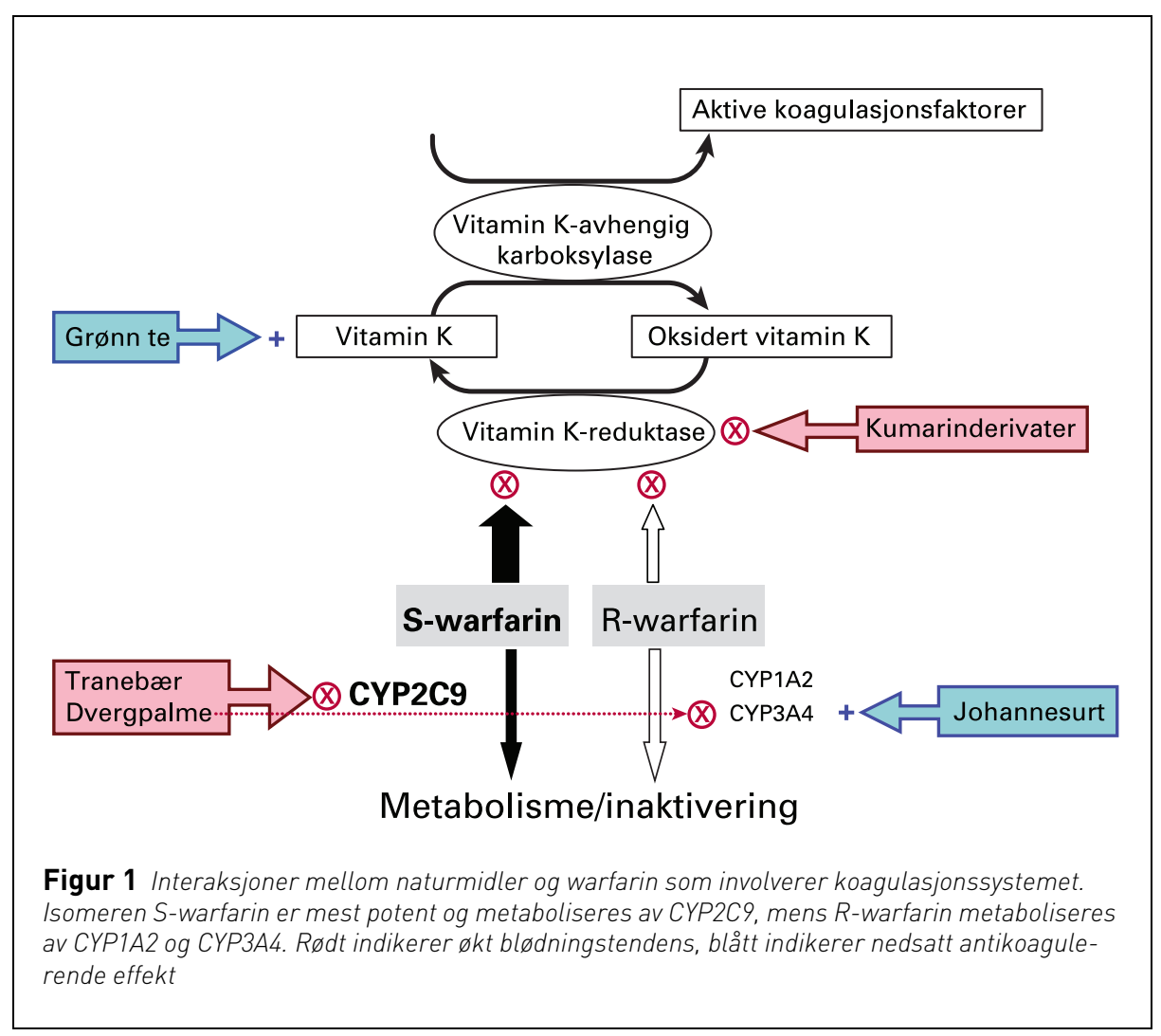

tas før det har effekt på blodplatene. Inntak av $10 \mathrm{~g}$ hvitløk ga økt levringstid, mens 4,2 g ikke påvirket blodplatefunksjonen (8). Kasuistikker har vist økt blødningstendens ved inntak av høye doser hvitløk (9). Funnene tyder på at hvitløkens effekt på blodplater er doserelatert og at relativt høye doser er nødvendig før blodplateaggregeringen påvirkes.

Også andre naturmidler inneholder stoffer med blodplatehemmende egenskaper som kan øke blødningsrisikoen i kombinasjon med warfarin. Kasusrapporter har vist at ginkgo har gitt blødning både alene og i kombinasjon med warfarin, og det er foreslått at dette skyldes blodplatehemmende effekt (4). Imidlertid har prospektive studier ikke funnet noen sammenheng mellom inntak av ginkgo og blødning (Interaktionsdatabasen.dk). Dette er nok et eksempel på at funn i kasusrapporter ikke alltid lar seg reprodusere i kontrollerte studier. I andre tilfeller er interaksjoner mellom naturmidler og warfarin av mer teoretisk karakter, fordi kliniske studier eller kasusbeskrivelser ikke finnes, men in vitro-studier har vist blodplatehemmende effekt. Hestekastanje og

Tabell 1 Klinisk relevante interaksjoner mellom naturmidler og warfarin

\section{Naturmiddel (latinsk navn)}

Ginseng (Panax ginseng)

Grønn te-ekstrakt (Camellia sinensis) Nedsatt antikoagulerende

Johannesurt (Hypericum perforatum)

Soyapreparater

Dong quai (Angelica sinensis)

Tranebær (Vaccinium macrocarpon)

Ginkgo (Ginkgo biloba)

Dvergpalme (Serenoa repens)

Hvitløk (Allium sativum) effekt

\section{Utfall}

Nedsatt antikoagulerende effekt effekt

Nedsatt antikoagulerende effekt

$\emptyset k t$ blødningsrisiko

$\emptyset k t$ blødningsrisiko

$\emptyset k t$ blødningsrisiko

$\emptyset k t$ blødningsrisiko

$\emptyset k t$ blødningsrisiko
Mulig mekanisme

Ukjent

Inneholder vitamin $\mathrm{K}$

Induksjon av CYP3A4/CYP2C9 Studie

Ukjent

Inneholder kumarinderivat

Hemmer CYP2C9

Hemmer blodplater

Hemmer CYP2C9/CYP3A4

Hemmer blodplater

Kasus

Kasus

Kasus

Kasus

Kasus

Kasus

\section{Kunnskaps- grunnlag}

Studie Interaktionsdatabasen.dk Lexi-Interact

Kasus Daugherty \& Smith (6)
Interaktionsdatabasen.dk Lexi-Interact

Holbrook et al (5), Daugherty \& Smith (6)

Lexi-Interact

Interaktionsdatabasen.dk Lexi-Interact

Interaktionsdatabasen.dk Lexi-Interact

Läkemedelsverket (7)

Lexi-Interact

${ }^{1}$ Vist i kasusrapport(er), men har motstridende resultater fra studier 
matrem er eksempler på naturmidler som har vist blodplatehemmende egenskaper in vitro, men der en interaksjon med warfarin ikke er klinisk dokumentert (10). Det er likevel grunn til å advare warfarinbrukere mot bruk av naturmidler som kan ha blodplatehemmende egenskaper.

\section{Konklusjon}

Det er kjent at noen naturmidler interagerer med warfarin, og disse bør unngås hos warfarinpasienter. For de fleste naturmidler er eventuell interaksjon med warfarin ukjent. Basert på begrenset effektdokumentasjon vil nytten av naturmidler sjelden veie opp for risiko for interaksjoner. Dersom pasienter likevel ønsker å bruke naturmidler, må INRverdi monitoreres ved oppstart, doseøkning, seponering og eventuelt ved bytte til nytt produksjonsnummer eller produkt med annen produsent. Måling av INR-verdi bør følges av en klinisk vurdering for å oppdage tegn på blødning og tromboemboli.

Oppgitte interessekonflikter: Ingen

\section{Litteratur}

1. Statens legemiddelverk. Bivirkningsrapport 2008. www.legemiddelverket.no (17.6.2009).
2. Wittowsky Ak. Dietary supplements, herbs and oral anticoagulants: the nature of evidence. J Thromb Thrombolysis 2008; 25: 72-7.

3. Leung VW, Shalansky SJ, Lo MK et al. Prevalence of use and the risk of adverse effects associated with complementary and alternative medicine in a cohort of patients receiving warfarin. Ann Pharmacother 2009; 43: 875-81.

4. Nutescu EA, Shapiro NL, Ibrahin S et al. Warfarin and its interactions with foods, herbs and other dietary supplements. Expert Opin Drug Saf 2006; 5: 433-51.

5. Holbrook AM, Pereira JA, Labiris R et al. Systematic overview of warfarin and its drug and food interactions. Arch Intern Med 2005; 165 : 1095-106.

6. Daugherty NE, Smith KM. Dietary supplements and selected food interactions with warfarin. Orthopedics 2006: 29: 309-14.

7. Läkemedelsverket. Förstärkt warfarineffekt av naturläkemedlet Curbisal - relaterat till innehåll av sågpalmetto? www.lakemedelsverket.se (17.6.2009).

8. Williamson E, Driver S, Baxter K, red. Stockley's herbal medicines interactions. London: Pharmaceutical Press, 2009

9. Scharbert G, Kalb ML, Duris M et al. Garlic at dietary doses does not impair platelet function. Anesth Analg 2007; 105: 1214-8

10. Natural Medicines Comprehensive Database. Feverfew, horse chestnut. www. naturaldatabase.com/ (17.6.2009).

Manuskriptet ble mottatt 30.6. 2009 og godkjent 4.3. 2010. Medisinsk redaktør Trine B. Haugen. 